Finanse, Rynki Finansowe, Ubezpieczenia nr 3/2017 (87), cz. 1

\title{
Usługi doradcze audytu wewnętrznego w samorządzie terytorialnym według badań ankietowych
}

\author{
Piotr Soltyk"
}

\begin{abstract}
Streszczenie: $\mathrm{Cel}$ - Zasadniczym celem artykułu jest prezentacja wybranych wyników badań własnych, którymi była ocena realizacji usług doradczych audytu wewnętrznego na płaszczyźnie samorządu terytorialnego.

Metodologia badania - Analizę materiału empirycznego przeprowadzono na podstawie kwestionariusza ankiety. W przygotowaniu wyników badań pomocne okazały się także studia literaturowe. Dodatkowo przeprowadzono również analizę regulacji prawnych, a także wytycznych profesjonalnej praktyki zawodowej ogłoszonych w drodze komunikatu.

Wynik - Prezentowane wyniki badań są kontynuacją wcześniejszych analiz dotyczących skuteczności i efektywności kontroli zarządczej, w tym audytu wewnętrznego. Uzyskane wyniki mogą stanowić podstawę do dalszych dyskusji nad modelem audytu wewnętrznego w sektorze finansów publicznych.

Oryginalność/wartość - W artykule sformułowano hipotezę, zgodnie z którą współczesny audyt wewnętrzny poprzez świadczenie na rzecz kierownictwa jednostki usług doradczych, staje się jednym z fundamentalnych instrumentów wspomagających proces zarządzania.
\end{abstract}

Słowa kluczowe: audyt wewnętrzny, doradztwo, samorząd terytorialny, ryzyko

\section{Wprowadzenie}

Współczesne potrzeby kierowania złożonymi procesami gospodarki finansowej w sektorze publicznym wymagają od decydentów wysokiego poziomu sprawności działania a także umiejętności i wiedzy specjalistycznej, niezbędnej do skutecznego zarządzania. Jednym z walorów procesu decyzyjnego jest pozyskanie informacji stanowiącej podstawę podejmowania decyzji zarządczych. Przygotowanie decyzji, w warunkach dużej zmienności otoczenia, dynamicznego rozwoju techniki, globalizacji procesów gospodarczych oraz w warunkach niepewności i ryzyka, wymaga stałego dopływu pełnych, szybkich i rzetelnych informacji (Filipiak, Dylewski, Gorzałczyńska-Koczkodaj, 2011, s. 9). W działalności jednostek sektora finansów publicznych wśród wielu instrumentów odpowiedzialnych za dostarczanie bieżącej i precyzyjnej informacji wykorzystywanej na potrzeby realizacji zadań

\footnotetext{
* dr Piotr Sołtyk, Uniwersytet Ekonomiczny w Krakowie, Wydział Finansów i Prawa, Katedra Finansów Samorządowych, e-mail: piotr.soltyk@uek.krakow.pl.
} 
publicznych, a także zarządzania budżetem (planem finansowym), należy wskazać niezależny audyt wewnętrzny. Bez wątpienia niezależna i obiektywna aktywność audytu wewnętrznego, w szczególności przez świadczenie na rzecz kierownictwa usług doradczych, wpisuje się w nurt nowego zarządzania w sektorze publicznym. Potrzebę wykonywania usług doradczych dostrzegł ustawodawca, określając w przepisach ustawy o finansach publicznych czynności doradcze, jako jedno z wielu zadań zarezerwowanych dla audytu wewnętrznego (por. Winiarska, 2007, s. 41-42).

Celem artykułu jest przedstawienie wybranych wyników badań własnych, przedmiotem których była ocena realizacji usług doradczych audytu wewnętrznego w jednostkach samorządu terytorialnego (dalej: JST).

\section{Czynności doradcze audytu wewnętrznego w świetle regulacji prawnych i wytycznych praktyki zawodowej}

Wymogi prawne w przedmiocie realizacji czynności doradczych uregulowano w rozporządzeniu Ministra Finansów z dnia 4 września 2015 roku w sprawie audytu wewnętrznego oraz informacji o pracy i wynikach tego audytu. Współczesny audytor wewnętrzny postrzegany jest jako niezależny diagnosta systemów zarządzania, który uprawniony jest do wykonywania usług doradczych na rzecz kierownika jednostki. Fundamentalnym celem czynności doradczych jest bieżące wspieranie decydentów w realizacji założonych celów i zdań. Świadczenie czynności doradczych następuje z własnej inicjatywy audytora lub na wniosek kierownika jednostki. Mając na uwadze znaczenie dostarczanej informacji przez audytora wewnętrznego, zasadne wydaje się, aby każdorazowo zakres i cel czynności doradczych wcześniej uzgodniono ze zleceniodawcą.

Wytyczne standardów audytu wewnętrznego dla jednostek sektora finansów publicznych z dnia 12 grudnia 2016 roku jednoznacznie wskazują, że ze względu na swój charakter czynności doradcze są z reguły wykonywane w odpowiedzi na konkretne zapotrzebowanie kierownika jednostki1. Istotą usług doradczych jest to, że zwykle angażują dwie strony, tj. osobę lub grupę osób oferujących doradztwo - audytora wewnętrznego, biegłego rewidenta lub doradcę podatkowego oraz osobę lub grupę osób poszukujących i uzyskujących konkretną poradę (por. Standardy audytu wewnętrznego..., 2016). Podobnie jak w przypadku realizacji zadania zapewniającego ${ }^{2}$ rezultatem końcowym czynności doradczych jest przede wszystkim sformułowanie właściwych propozycji przyczyniających się do usprawnienia funkcjonowania w jednostce systemów zarządzania. W wyniku czynności doradczych powinna powiększyć się jakość i efektywność działania obszaru, który był

\footnotetext{
${ }^{1}$ Komunikat Ministra Rozwoju i Finansów z dnia 12 grudnia 2016 r. w sprawie standardów audytu wewnętrznego dla jednostek finansów publicznych (Dz. Urz. Min. Rozw. i Fin. poz. 28).

${ }^{2}$ Zgodnie z rozporządzeniem Ministra Finansów z dnia 4 września 2015 r. w sprawie audytu wewnętrznego oraz informacji o pracy i wynikach tego audytu - przez zadanie zapewniające należy rozumieć działania podejmowane w celu dostarczenia niezależnej i obiektywnej oceny kontroli zarządczej.
} 
przedmiotem konsultacji. Wszyscy audytorzy wykonujący czynności doradcze zobowiązani są do przestrzegania standardów profesjonalnej praktyki zawodowej. Chodzi przede wszystkim o respektowanie standardów zawodowych odnoszących się do obiektywizmu, biegłości i należytej staranności zawodowej audytu wewnętrznego (por. Standardy audytu wewnętrznego..., 2016). Biorąc pod uwagę złożoność realizowanych zadań audytowych, aktywność współczesnego audytu wewnętrznego w większym stopniu powinna zostać ukierunkowana na doradztwo i konsulting, z wykorzystaniem różnorodnych metod zarządzania ryzkiem, sygnalizując na bieżąco decydentom ryzyko niepowodzeń i innych dysfunkcji. Niejednokrotnie właściwa porada audytora wewnętrznego może ustrzec decydenta samorządowego przed niebezpiecznym ryzykiem odpowiedzialności za naruszenie dyscypliny finansów publicznych.

\section{Założenia metody badawczej}

Podstawę do analizy materiału empirycznego stanowił kwestionariusz ankiety, który skierowano do wybranych JST na terenie województwa świętokrzyskiego. Wtórną analizę dokonano na podstawie 36 ankiet. Dążąc do rozpoznania rzeczywistego obrazu świadczonych usług doradczych przez audytorów wewnętrznych na polu samorządu terytorialnego, przyjęto założenia, że badane jednostki poddano stratyfikacji na poszczególne rodzaje JST, tj.: urząd marszałkowski, urząd miasta, urząd gminy i starostwo powiatowe. Podstawę do sformułowania pytań w kwestionariuszu ankiety stanowiły wytyczne standardów kontroli zarządczej ogłoszone Komunikatem nr 23 Ministra Finansów z dnia 16 grudnia 2009 roku³ Pomocne okazały się także wytyczne standardów zawodowych profesjonalnej praktyki audytorskiej ogłoszone w Komunikacie Ministra Rozwoju i Finansów z dnia 12 grudnia 2016 roku w sprawie standardów audytu wewnętrznego dla jednostek sektora finansów publicznych ${ }^{4}$. Horyzont czasowy badań obejmował lata 2010-2016, uwzględniając rozwiązania prawne regulujące metodykę audytu wewnętrznego ${ }^{5}$. Wyniki analizy w zakresie zlecania audytorowi czynności doradczych powinny dostarczyć odpowiedzi na wiele istotnych pytań, a mianowicie:

- czy kierownictwo JST zlecało audytorom wewnętrznym przeprowadzenie czynności doradczych,

- czy wpływ na zlecanie audytorom przeprowadzenia czynności doradczych ma wykształcenie kierowników JST,

- czy okres prowadzenia audytu w jednostce samorządowej ma wpływ na zlecanie czynności doradczych,

\footnotetext{
${ }^{3}$ Komunikat nr 23 Ministra Finansów z dnia 16 grudnia 2009 r. w sprawie standardów kontroli zarządczej dla sektora finansów publicznych (Dz. Urz. Min. Fin. nr 15, poz. 84).

${ }^{4}$ Dz. Urz. Min. Rozw. i Fin. poz. 28.

${ }^{5}$ Rozporządzenie Ministra Finansów z dnia 4 września 2015 r., w sprawie audytu wewnętrznego oraz informacji o pracy i wynikach tego audytu (Dz.U. z 2015 r., poz. 1480).
} 
- jak kształtowało się zapotrzebowanie na usługi doradcze w okresie ostatnich dwóch lat w JST.

- czy udzielanie czynności doradczych miało wpływ na niezależność audytorów.

\section{Prezentacja wybranych wyników badań}

Bardzo interesujące wyniki przyniosło badanie dotyczące zlecania audytorom wewnętrznym przeprowadzenia czynności doradczych. Okazało się, że 75\% kierownictwa JST wykorzystuje funkcję doradczą audytu wewnętrznego. Według kierownictwa, informacja uzyskiwana dzięki czynnościom doradczym jest bardzo przydatna w podejmowaniu decyzji oraz w zarządzaniu gospodarką finansową. Ponadto decydenci samorządowi bardzo pozytywnie oceniają tę formę audytu, gdyż zakres czynności dostosowany jest do potrzeb zlecającego, a temat nie musi wynikać z obszaru objętego audytem i być określony w rocznym planie audytu. Ponadto 26\% kierowników uważa, że audyt może spełniać szczególnie aktywną rolę doradczą w JST, które nie mają wdrożonego systemu zarządzania ryzykiem. Jak wskazują wyniki badań, 75\% decydentów samorządowych zleca audytorom wewnętrznym przeprowadzanie zadań doradczych. Nie jest to rezultat zadowalający, jeżeli uwzględnimy opinie 25\% kierowników JST, którzy nie wyrażają woli zlecania takiej formy prowadzenia audytu.

Analiza wyników badań dowiodła, że czynności doradcze są nieodzownym elementem pracy audytorów wewnętrznych zatrudnionych w urzędach marszałkowskich - 100\% respondentów potwierdziło tę tezę. O bardzo dużym znaczeniu czynności doradczych w gospodarowaniu finansami JST wypowiedzieli się również kierownicy urzędów starostw powiatowych $(80 \%)$. W pozostałych badanych typach JST, respondenci również wyrazili pogląd, że zlecają audytorowi czynności doradcze - urzędy gmin - 71\% i urzędy miast $63 \%$. Oznacza to, że kierownicy tych jednostek widząc potrzebę formy doradczej audytu, wykorzystują różnego rodzaju zalecenia, rekomendowanie usprawnień, jak również uważają za przydatne proponowane w ten sposób zmiany planów i inicjatyw. Respondenci uważają, że obiektywne i kompetentne doradztwo audytu wewnętrznego jest formą aktualnego rozwiązywania problemów w działalności operacyjnej JST.

Na uwagę zasługuje to, że 36\% respondentów z urzędów miast wyraziło opinię, iż nie korzysta z usług audytu wewnętrznego. Podobną opinię uzyskano od kierowników z urzędów starostw powiatowych, w których 20\% respondentów jednoznacznie stwierdziło, że nie zleca audytorowi przeprowadzenia czynności doradczych. Może to świadczyć o braku zaufania do informacji formułowanej przez audyt lub też o niewystarczającym rozeznaniu w idei i faktycznych możliwościach audytu w sektorze publicznym. Wytłumaczeniem tego może być również korzystanie przez kierownictwo z usług doradczych świadczonych przez radców prawnych, biegłych rewidentów lub skarbników. Wyniki badań dotyczących zlecania audytorowi przeprowadzenia czynności doradczych przedstawiono na rysunku 1. 


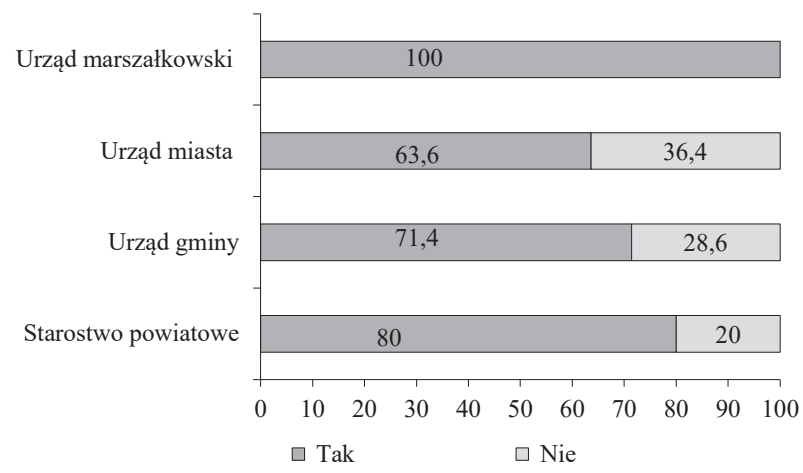

Rysunek 1. Zlecanie audytorowi czynności doradczych

Źródło: obliczenia własne na podstawie badań ankietowych.

Starano się również oszacować - wyjaśnić, jaki wpływ na zlecanie audytorom przeprowadzenia czynności doradczych ma wykształcenie kierowników JST. Wyniki badań nie są jednoznaczne, ponieważ 74,1\% kierowników z wyższym wykształceniem, 88\% kierowników z wykształceniem niepełnym wyższym oraz $83,3 \%$ kierownictwa z wykształceniem średnim widzi potrzebę zlecania audytorowi czynności doradczych. Aż 25,9\% kierownictwa legitymującego się wyższym wykształceniem, 12\% kierowników z wykształceniem niepełnym wyższym oraz $16,7 \% \mathrm{z}$ wykształceniem średnim nie korzysta jednak z usług audytu wewnętrznego.

Korzystanie przez kierownictwo z usług doradczych audytorów wewnętrznych może świadczyć o tym, że decydenci samorządowi obdarzyli audytorów dużym zaufaniem, są w stanie polegać na ich opiniach oraz doceniają profesjonalizm w działaniach komórki audytu wewnętrznego (dalej: KAW). Może to również wynikać ze zrozumienia filozofii teraźniejszego audytora wewnętrznego, który coraz częściej postrzegany jest jako konsultant. Negatywne nastawienie do działań audytorów wewnętrznych świadczy natomiast o braku zaufania do opinii audytora i bazowaniu na opiniach wyrażanych przez inne gremia doradcze, takie jak: radca prawny, doradca, biegły rewident lub skarbnik. Takie postępowanie kierownictwa budzi podejrzenie o niepełnym rozumieniu faktycznych zalet i możliwości, jakie niesie niezależna i obiektywna działalność audytu wewnętrznego w jednostkach podsektora samorządowego. Wyniki badań dotyczące zlecania czynności doradczych w zależności od wykształcenia kierownictwa JST przedstawiono na rysunku 2.

Równie ważnym zagadnieniem, z punktu widzenia usług doradczych audytu, było ustalenie czy okres prowadzenia audytu w JST wpływa na zlecanie audytorowi czynności doradczych. Okazało się, że korzystanie z porad audytu wewnętrznego nie jest uzależnione od okresu jego prowadzenia w jednostce samorządowej. Świadczyły o tym wypowiedzi $66,7 \%$ respondentów z jednostek samorządu terytorialnego, które prowadzą audyt dłużej niż 5 lat. $\mathrm{Z}$ wypowiedzi tych wynikało, że nie ma potrzeby korzystania z porad audytora $\mathrm{w}$ zakresie 
działań doradczych. Wypowiedzi takie nie dziwią, ponieważ decydenci samorządowi zazwyczaj korzystają z porady audytora w sytuacjach nagłych, bezzwłocznie wymagających merytorycznej informacji, a sama procedura zadania doradczego nie jest objęta takimi wymogami formalno-prawnymi, jak dla zadania zapewniającego (zadanie doradcze audytu nie musi być określone w rocznym planie audytu, nie ma obowiązku przeprowadzania analizy ryzyka). W tabeli 1 przedstawiono wyniki badań w zakresie zlecania czynności doradczych w zależności od okresu prowadzenia komórki audytu wewnętrznego w JST.

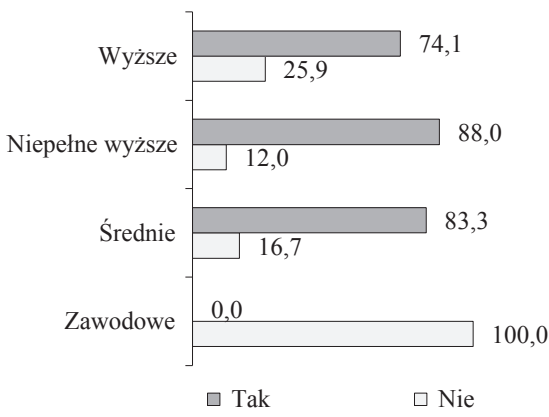

Rysunek 2. Zlecenie audytorowi czynności doradczych w zależności od wykształcenia kierownika JST

Źródło: obliczenia własne na podstawie badań ankietowych.

\section{Tabela 1}

Zlecanie czynności doradczych w zależności od jak dawna prowadzony jest audyt

\begin{tabular}{lllllr}
\hline \multicolumn{6}{l}{ Od jak dawna prowadzony jest audyt wewnętrzny $(\%)$} \\
\hline \\
\hline Tak & dłużej niż 5 lat & 5-4 lata & 3-2 lata & rok & krócej niż rok \\
Nie & 33,3 & 25,0 & 10,0 & 50,0 & 0,0 \\
\hline
\end{tabular}

Źródło: obliczenia własne na podstawie badań ankietowych.

Kluczowe dla dalszych rozważań jest określenie, jaki jest procentowy udział czynności doradczych w codziennej pracy audytora w JST. Wypowiedzi osób badanych pokazują, że 42,9\% audytorów uważa, iż czynności doradcze w ich codziennej pracy kształtują się od 15 do $20 \%$. Tylko 17,1\% respondentów wyraziło opinię, że kierownictwo absorbuje czas audytorów zlecając im udzielanie porad doradczych na poziomie od 10 do $15 \%$, a tylko 5,7\% badanych stwierdziło, że usługi doradcze stanowią ponad 50\% ich codziennej pracy. Taka sytuacja w głównej mierze spowodowana jest niewystarczającą znajomością KAW przez kierownictwo, a w szczególności nieznajomością faktycznych zalet oraz celów stawianych przed audytem wewnętrznym w sektorze publicznym, zwłaszcza funkcji doradczej, prewencyjnej, empirycznej i oceniającej. Występującą dysfunkcję można również upatrywać 
w samym procesie organizacji systemu audytu, tj. w przewadze zadań zapewniających nad zadaniami diagnostyczno-prewencyjnymi audytu (zapobiegawczymi materializacji ryzyka nieprawidłowości). W tabeli 2 i na rysunku 3 zaprezentowano wyniki badań w tym zakresie.

\section{Tabela 2}

Udział czynności doradczych w czasie pracy audytora w JST

\begin{tabular}{llllll}
\hline \multicolumn{7}{l}{ Typ jednostki samorządu terytorialnego (\%) } & & & \\
\hline udział & urząd marszałkowski & urząd miasta & urząd gminy & starostwo powiatowe & ogółem \\
\hline do $5 \%$ & 0,0 & 27,3 & 16,7 & 26,7 & 2,9 \\
$5-10 \%$ & 0,0 & 9,1 & 16,7 & 0,0 & 5,7 \\
$10-15 \%$ & 33,3 & 9,1 & 0,0 & 26,7 & 17,1 \\
$15-20 \%$ & 33,3 & 27,3 & 33,3 & 13,3 & 42,9 \\
$20-25 \%$ & 0,0 & 0,0 & 0,0 & 26,7 & 11,4 \\
$30-40 \%$ & 0,0 & 9,1 & 16,7 & 6,7 & 8,6 \\
$40-50 \%$ & 0,0 & 9,1 & 16,7 & 0,0 & 5,7 \\
ponad 50\% & 33,3 & 9,1 & 0,0 & 0,0 & 5,7 \\
\hline
\end{tabular}

Źródło: obliczenia własne na podstawie badań ankietowych.

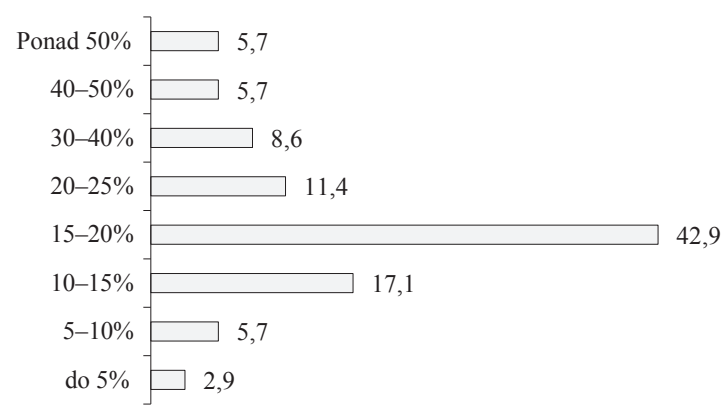

Rysunek 3. Udział czynności doradczych w czasie pracy audytora w JST

Źródło: obliczenia własne na podstawie badań ankietowych.

Interesujące są również oceny audytorów wewnętrznych związane z określeniem tego, jakie było zapotrzebowanie na usługi doradcze audytu wewnętrznego, biorąc pod uwagę okres dwóch ostatnich lat. Aż 40\% badanych uważa, że w ostatnim okresie nastąpił istotny wzrost świadczonych porad doradczych na rzecz kierownictwa i innych pracowników jednostki. Wyniki badań nie dziwią, gdyż z samej definicji audytu wewnętrznego wynika, że skupia się on na weryfikacji całych systemów, w związku z czym samo zidentyfikowanie luk i błędów w badanym procesie nie stanowi trudności, a wydawane rekomendacje mają zapobiec ponownemu wystąpieniu nieprawidłowości. Taki istotny wzrost czynności doradczych audytu może być spowodowany wzrostem zaufania do wiedzy i doświadczenia 
audytorów. Nie należy również zapominać o coraz częściej spotykanym terminie marketingu rangi i wartości wnoszonej przez audyt w jednostce, która może być skutecznie realizowana przez m.in. bieżącą informację o grożącym ryzyku nieprawidłowości oraz szeroko rozumiane zadania konsultacyjne.

$\mathrm{Z}$ danych uzyskanych w badaniu wynika również, że 54\% respondentów z urzędów miast uważa, że nastąpił zdecydowany wzrost udziału czynności doradczych w pracy KAW w ostatnich dwóch latach, zaś w pozostałych JST respondenci uważają, że nastąpił nieznaczny wzrost. Tylko 3\% badanych wyraża opinię o zmniejszeniu się udziału porad doradczych w pracy KAW w ostatnim czasie, a $11 \%$ badanych nie ma zdania na ten temat. W tabeli 3 i na rysunku 4 przedstawiono wyniki badań empirycznych dotyczących udziału czynności doradczych, w czasie pracy audytora wewnętrznego w ostatnich dwóch latach.

\section{Tabela 3}

Udział czynności doradczych w czasie pracy audytora w ostatnich dwóch latach

\begin{tabular}{|c|c|c|c|c|c|}
\hline \multicolumn{6}{|c|}{ Typ jednostki samorządu terytorialnego (\%) } \\
\hline Udział & urząd marszałkowski & urząd miasta & urząd gminy & starostwo powiatowe & ogółem \\
\hline Silny wzrost & 0,0 & 9,1 & 0,0 & 0,0 & 2,9 \\
\hline Wzrost & 33,3 & 54,5 & 33,3 & 33,3 & 40,0 \\
\hline Bez zmian & 66,7 & 36,4 & 33,3 & 20,0 & 31,4 \\
\hline Spadek & 0,0 & 0,0 & 16,7 & 20,0 & 11,4 \\
\hline Silny spadek & 0,0 & 0,0 & 0,0 & 6,7 & 2,9 \\
\hline Trudno powiedzieć & 0,0 & 0,0 & 16,7 & 20,0 & 11,4 \\
\hline
\end{tabular}

Źródło: obliczenia własne na podstawie badań ankietowych.

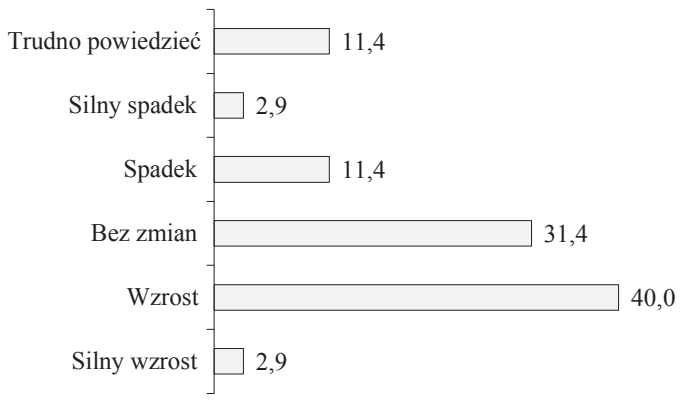

Rysunek 4. Udział czynności doradczych w czasie pracy audytora w ostatnich dwóch latach

Źródło: obliczenia własne na podstawie badań ankietowych.

Kolejne zagadnienie, z punktu widzenia świadczonych przez audytorów wewnętrznych porad doradczych, dotyczyło określenia wpływu udzielanych czynności doradczych na niezależność audytorów. 
Z badań empirycznych jednoznacznie wynika, że $28,6 \%$ ankietowanych audytorów wewnętrznych łamie zasadę niezależności podczas udzielania porad doradczych. Za istotny czynnik wpływający na nieprzestrzeganie wytycznych standardów zawodowych, podczas świadczonych usług doradczych, jest wola kierownictwa jednostki o angażowaniu audytora w działalność nie zawsze związaną z pracą audytora. 40\% ankietowanych zadeklarowało, że nie ma konfliktu z kierownictwem jednostki i przestrzega każdorazowo standardów zawodowych dotyczących niezależności oraz obiektywizmu w toku udzielania porad doradczych. Wysoki odsetek ankietowanych - (31\%) stwierdziło, że nie ma zdania. Z badań wynika również, że 50\% ankietowanych audytorów z urzędów gmin jest przekonanych o nieprzestrzeganiu istotnych standardów niezależności i obiektywizmu podczas świadczenia usług doradczych. Problemy z niezależnością zgłosiło również 33\% ankietowanych z urzędów marszałkowskich oraz $26 \%$ z urzędów starostw powiatowych.

Duży odsetek ankietowanych nie potrafił jednoznacznie określić, czy podczas świadczenia usług doradczych łamane są standardy zawodowe - problem z jasnym zdefiniowaniem takiej sytuacji miało $40 \%$ respondentów ze starostw powiatowych, $36 \%$ z urzędów miast oraz $16 \%$ audytorów z urzędów gmin. Są to niezbyt zadowalające wyniki, szczególnie te uzyskane od respondentów z urzędów starostw powiatowych, w których aż $40 \%$ ankietowanych niejednoznacznie zadeklarowało przestrzeganie jednej z podstawowych zasad audytu - niezależności, a tylko $33 \%$ badanych wyraziło opinię, że nie łamie wytycznych w zakresie tego standardu zawodowego. Na rysunku 5 przedstawiono wyniki badań ankietowych dotyczących powyższych zagadnień.

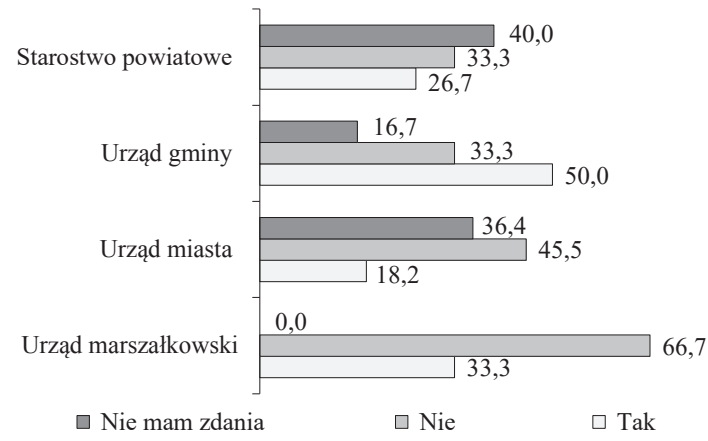

Rysunek 5. Wpływ czynności doradczych na niezależność i obiektywizm audytora

Źródło: obliczenia własne na podstawie badań ankietowych. 


\section{Uwagi końcowe}

Konkluzje płynące z analizy wyników badań dotyczących świadczenia przez audytorów wewnętrznych usług doradczych, są następujące:

1. Zdecydowana większość kierownictwa jednostek samorządowych $-75 \%$ jest zdania, że rola doradcza audytu jest integralną częścią funkcjonowania całego systemu zarządzania i wykorzystuje efektywnie tę funkcję. Informacja uzyskiwana z czynności doradczych audytora jest bardzo przydatna w podejmowaniu bieżących decyzji przez decydentów samorządowych, zwłaszcza w procesie zarządzania gospodarką finansową jednostki. 75\% kierownictwa JST zleca audytorom przeprowadzenie porad doradczych, oceniając tę formę audytu za bardzo wygodną, dostosowaną do potrzeb zlecającego, bez konieczności zachowania wymagań proceduralnych audytu.

2. Badania dowodzą, że w większym stopniu przeprowadzenie czynności doradczych zlecają kierownicy legitymujący się wykształceniem wyższym - (74\%), co może świadczyć o pełniejszym zrozumieniu filozofii współczesnego audytu i wnoszeniu do jednostki wartości dodanej. Ogólny wniosek, jaki można wyciągnąć po przeanalizowaniu uzyskanych danych, sprowadza się do stwierdzenia, że decydenci najczęściej korzystają z porad audytora w przedmiocie obszarów narażonych na ryzyko naruszenia przepisów Ustawy z dnia 17 grudnia 2004 roku o odpowiedzialności za naruszenie dyscypliny finansów publicznych.

3. 43\% audytorów uważa, że czynności doradcze zajmują im 15-20\% codziennej pracy, poza wyjątkami odnotowanymi w urzędach starostw powiatowych i w urzędach miast. Ponadto $40 \%$ badanych audytorów uważa, że w ostatnim okresie nastąpił silny wzrost świadczonych porad doradczych na rzecz kierownictwa i innych pracowników jednostki, a tylko 3\% ankietowanych wyraziło opinię, że nastąpił silny spadek.

Z badań wynika, że 30\% audytorów wewnętrznych nie przestrzega zasady niezależności podczas udzielania porad doradczych, podając jednocześnie, że istotnym czynnikiem wpływającym na nieprzestrzeganie wytycznych i standardów zawodowych jest wola kierownictwa jednostki o angażowaniu audytora w działalność nie zawsze związaną z działalnością audytorską. Okazało się również, że korzystanie z porad audytu wewnętrznego nie jest uzależnione od okresu jego prowadzenia w jednostce. Świadczenie usług doradczych w dużej mierze zależy od predyspozycji, doświadczenia i wiedzy audytora wewnętrznego.

\section{Literatura}

Filipiak, B., Dylewski, M., Gorzałczyńska-Koczkodaj, M. (2011). Analiza finansowa budżetów jednostek samorzadu terytorialnego. Warszawa: Municipium.

Komunikat nr 23 Ministra Finansów z dnia 16 grudnia 2009 r. w sprawie standardów kontroli zarządczej dla sektora finansów publicznych (Dz. Urz. Min. Rozw. i Fin. poz. 28).

Komunikat Ministra Finansów z dnia 12 grudnia 2016 r. w sprawie standardów audytu wewnętrznego dla jednostek sektora finansów publicznych (Dz. Urz. Min. Fin. poz. 15). 
Rozporządzenie Ministra Finansów z dnia 4 września 2015 r. w sprawie audytu wewnętrznego oraz informacji o pracy i wynikach tego audytu (Dz.U. poz. 1480).

Winiarska, K. (2007). Audyt wewnętrzny w 2007 roku. Standardy międzynarodowe-Regulacje krajowe. Warszawa: Difin.

\section{INTERNAL AUDIT CONSULTING SERVICES IN LOCAL GOVERNMENT ACCORDING TO SURVEYS}

Abstract: Purpose - The main aim of the article is to present selected results of own research on the implementation of internal audit advisory services in local government units.

Design/methodology/approach - The empirical data was analyzed on the basis of the questionnaire survey. Literature studies have also helped in the preparation of research results, as well as an analysis of legal regulations and communications.

Findings - The presented results are a continuation of previous analyzes on the effectiveness and effectiveness of management control and internal audit. The results obtained may provide the basis for further discussions on the internal audit model in the public finance sector.

Originality/value - The paper hypothesizes that contemporary internal auditing by providing the management unit with consulting services becomes one of the permanent instruments supporting the management process.

Keywords: internal audit, consulting, local government, risk

\section{Cytowanie}

Sołtyk, P. (2017). Usługi doradcze audytu wewnętrznego w samorządzie terytorialnym według badań ankietowych. Finanse, Rynki Finansowe, Ubezpieczenia, 3 (87/1), s. 43-53. DOI: 10.18276/frfu.2017.87/1-04. 